\title{
EVALUATION OF CHEMICAL PROCESS PARAMETERS IN WASTE DISPOSAL SITES BY SATELLITE IMAGES
}

\author{
Mihail Shakhramanyan, Andrey Richter, Maretta Kazaryan, Roumen Nedkov, Denitsa Borisova, Nataliya \\ Stankova, Iva Ivanova, Mariana Zaharinova
}

\begin{abstract}
The presented paper proposes a method for estimating parameters and characteristics of the chemical processes in large municipal landfills and solid waste disposal sites according to the waste monitoring from space. The model of chemical transformations in the waste disposal sites is described based on the idea of waste biochemical degradation in the form of the "transformations tree". The presentation of chemical transformations in the form of statistical integrated chemical equations allows us to describe the chemical system "a waste disposal facility" in the analytical form. The paper presents the main types of physical (volume and mass, thermal) and chemical (filtrate) characteristics which assessment could be made by data from satellite images. As an example the obtaining of the volume and mass characteristics of landfills in their 3D-models is described. Results of the algorithm on the example of a polygon of solid municipal and industrial waste in Salaryevo (Leninsky district of the Moscow region) are presented. As an example the assessment of volume and mass of landfill gas and its main component - methane is shown. An airborne image from year 2000 is compared with the satellite images in visible spectral range closed to its date. The main sources of errors in the evaluation of volume and mass characteristics are defined. The error which source is the spatial and spectral resolution of the satellite image is calculated.
\end{abstract}

Keywords: waste disposal facility, landfills, satellite images, chemical processes, chemical parameters, 3D-model

\section{INTRODUCTION}

In terms of biochemical processes dump is a chemically dangerous and one of the most complex objects, so complex that many chemical conversion and reaction products still remain a mystery. Solid waste landfill (SWL), especially municipal solid waste landfills (MSWLF), solid domestic waste (SDW) and industrial wastes (IW) are generators of extremely hazardous chemicals, such as dioxins and furans $[1-4]$.

A common process for all SWLs is the formation of the three matter fractions: liquid - filtrate and filtration drains, gaseous - biogas, landfill gas, and solid - the landfill soil humus. Weather conditions, particularly thermal radiation and rainfall, activate multiple chemical mechanisms and processes in a dumping landfill body, producing liquid, gaseous and solid (complex) compounds [5-9].

\section{MATERIALS}

In [10] a comprehensive chemical analysis of SWL as a result of long-term and labor-intensive studies of various garbage dumps and landfills is described. On the basis of field and laboratory methods and compilation of statistical data we obtained classification types of chemical reactions and chemical substances, general laws of chemical processes in landfills and migration of substances in the dump body and beyond.

The stage (phase) of waste degradation is a condition characterized by the ratio of the concentrations of indicator substances in the biogas and filtrate drain in the landfill which is in the current time (see Figure 1). Evolution of the dump passes in one direction: toward the decomposition of complex substances to simpler, oxygen consumption, complexation and humification, infiltration of volatile substances through the surface in the composition of biogas washing agents with weak association through filtrate, etc.[11-13].The process of biochemical degradation of waste in a landfill is unidirectional [14], in spite of the numerous branches of this main direction of evolution, constituting a deviation from the mean. In this regard, the material [10] is reduced to the analytical model of chemical transformations on SWL. In the Figure 2 a model of chemical transformations tree whose branches are elementary chemical transformations is shown. In the Figure 2: QC - carboxylic acids; LCD - fatty acids; a / b - a substance or b; a, b - a substance and b; I - aerobic stage, II-IV - anaerobic stage (II - phase atsetogenesis, III - the phase of active methanogenesis, IV - phase of stable methanogenesis), V - stage of humification. For each chemical conversion by methods of mathematical chemistry [15] the statistical integral equation in the form can be calculated [17]:

$$
\sum_{i=1}^{m} x_{i} A_{i}=\sum_{j=1}^{n} y_{j} B_{j}
$$


where $x_{i}$ - stochastic integral ratios of reactants, $A_{i}=\bigcup_{k=1}^{l} a_{k}\left(r_{k i}\right), y_{j}$ - products $B_{j}=\bigcup_{k=1}^{l} b_{k}\left(s_{k j}\right)\left(a_{k}\right.$ and $r_{k i}$ - chemical element, and the number of atoms of that element in the composition of compound $A_{i}$, $b_{k}$ and $s_{k j}-B_{j}$ connection) or in matrix form:

$$
\begin{gathered}
R \cdot x=S \cdot y \Rightarrow K \cdot z=0, K=\left[\begin{array}{ll}
-R & S
\end{array}\right], z=\left[\begin{array}{l}
x \\
y
\end{array}\right] \\
x=\left[\begin{array}{llll}
x_{1} & x_{2} & \ldots & x_{m}
\end{array}\right]^{T}, y=\left[\begin{array}{llll}
y_{1} & y_{2} & \ldots & y_{n}
\end{array}\right]^{T}, \\
R=\left[r_{k i}\right]_{l \times m}, S=\left[s_{k j}\right]_{l \times n}
\end{gathered}
$$

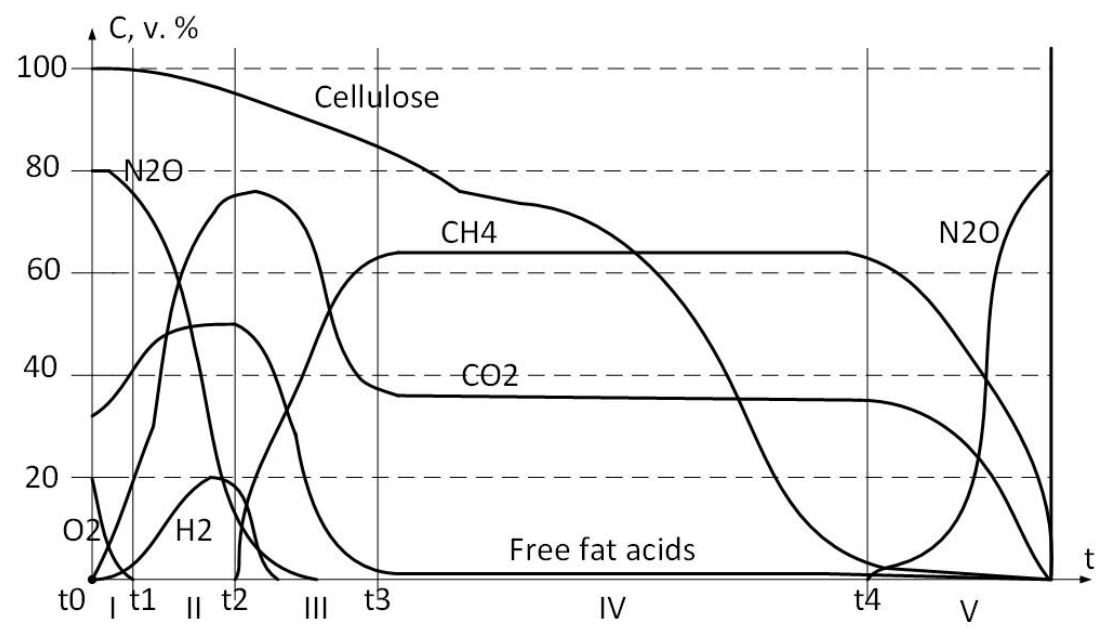

Fig. 1. Changes in the concentrations of substances in the composition of indicators, biogas, depending on the time evolution of the landfill

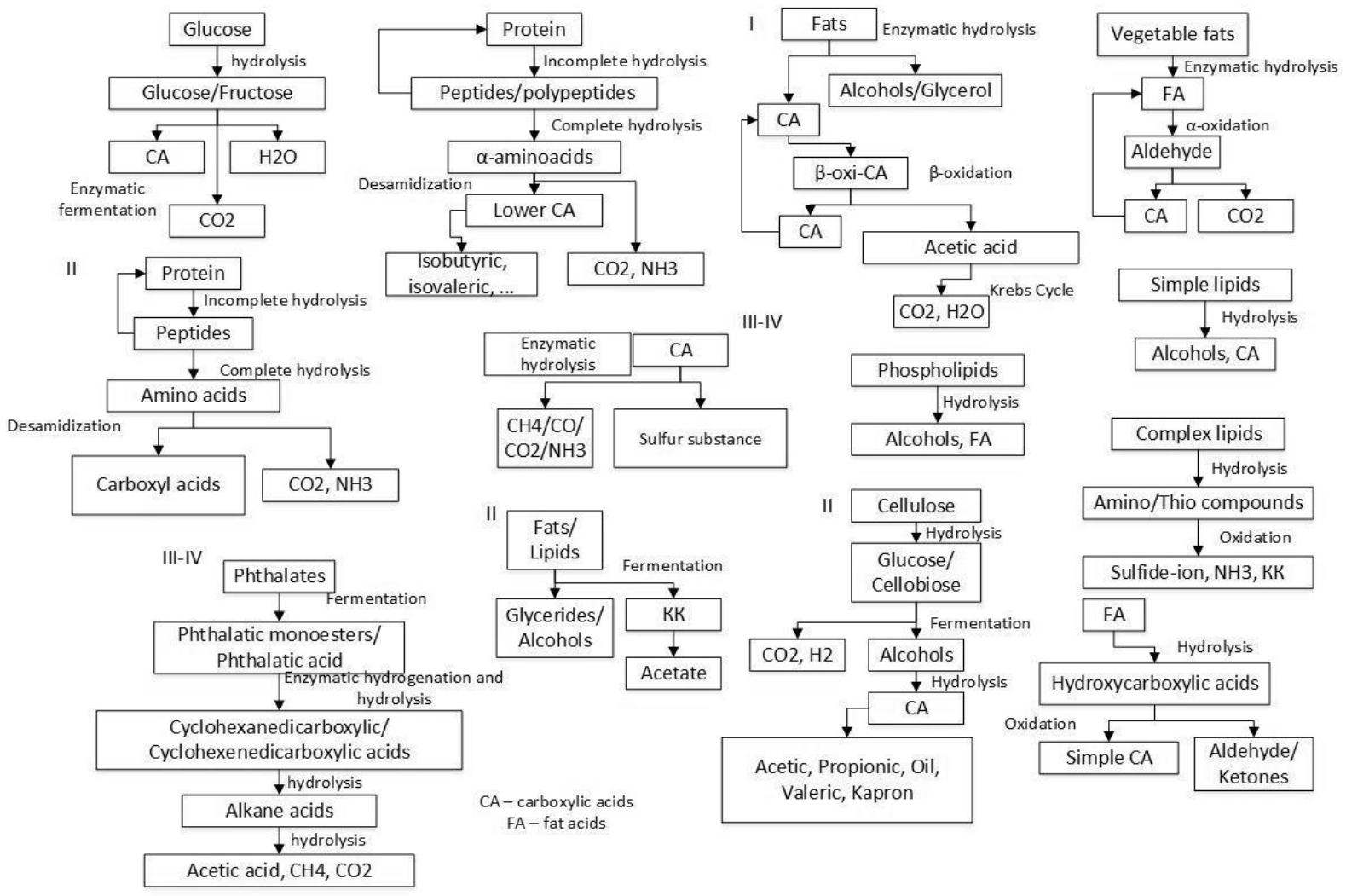

Fig. 2. Basic mechanisms of reaction in the landfills 
Related elementary transformations in the composition of the tree are bound by common substances. When connecting one of the previous conversion products is one of the following reagents, in parallel - one of the products (reactants) converting one coincides with one of the products (reactants) of the other. Common substances correspond to $\mathrm{z}_{1}$ independent solutions of the fundamental system of solutions of the homogeneous equation (2), the mass of which are given or derived from previous changes. $\mathrm{M}$ molar mass $\mathrm{m}$ and common substances:

$$
\begin{aligned}
& M=E \cdot K, \quad m_{i}=\Delta m_{i}+q \cdot M_{i}, q=\min _{i} \frac{m_{i}}{M_{i}}, \\
& E=\left[\begin{array}{lllll}
E_{1} & E_{2} & \ldots & E_{l}
\end{array}\right], \quad M=\left[\begin{array}{llll}
M_{1} & M_{2} & \ldots & M_{m+n}
\end{array}\right]
\end{aligned}
$$

where $q$ - equimolar amount of a chemical substance conversion have - atomic weight - weight of the $i$ - substance is not entered into the transformation reaction.

Equation (1) is a statistical, because substance $A_{i}$ and $B_{j}$ have a probabilistic nature, defining entire classes of chemicals. In this connection, the elements of $R$ and $S$ matrices are given by the statistical characteristics: expectation, standard deviation, correlation coefficients, initial and central moments.

\section{ALGORITHM}

Methods of space monitoring [18-21] enables to score a variety of chemical processes associated with the signs, which are reflected on the surface of the ground in the area of warehousing and in the vicinity: surface temperature, soil types and formations of fluid (Table 1).

Table 1. Basic physical and chemical parameters and characteristics of SWL and IW polygons

\begin{tabular}{|l|l|}
\hline Type & Parameters \\
\hline $\begin{array}{l}\text { Volume and mass } \\
\text { characteristics }\end{array}$ & $\begin{array}{l}\text { The volume and weight of components and biogas, volume of the solid element } \\
\text { clusters and landfill space and time, the density of matter, process parameters } \\
\text { (compression ratio, shrinkage, etc.) }\end{array}$ \\
\hline $\begin{array}{l}\text { Thermal } \\
\text { performances }\end{array}$ & $\begin{array}{l}\text { The amount of heat generated, the stage and stages of degradation, the intensity of } \\
\text { biochemical processes, thermal conductivity, heat balance }\end{array}$ \\
\hline $\begin{array}{l}\text { Features of the } \\
\text { filtrate }\end{array}$ & $\begin{array}{l}\text { Water balance, filter coefficients and velocity of spectra landfill filtrate and soil, } \\
\text { types of chemical reactions, the chemical composition and the soil components }\end{array}$ \\
\hline
\end{tabular}

Let us describe the preparation of certain bodymass characteristics of SWLs. For this purpose, radar images and statistical data on the chemical processes in landfills (biogas composition, the filtrate, they change depending on the stage, etc.), are derived from the normative-technical documentation or research [22].

Decomposition of $1 \mathrm{~m}^{3}$ of solid waste provides $1.5 \mathrm{~m}^{3}$ of biogas, i.e. [22], $V_{2}=1.5 \cdot V_{\text {swl }}, V_{s w l}$ - the volume of solid waste, $\mathrm{Vg}$ - limiting the amount of biogas from the decomposition of $V_{s w l}$ volume $\mathrm{m}^{3}$ of SWL. Volume ratio of the main components of biogas:

$$
\begin{aligned}
& V_{2 i}=k_{2 i} \cdot V_{2}, \quad \sum_{i=1}^{l} k_{2 i}=1, \quad \sum_{i=1}^{l} V_{2 i}=V_{2}, \\
& V_{2 i}(t)=k_{2 i}(t) \cdot V_{2}, \quad \sum_{i=1}^{l} k_{2 i}(t)=1, \\
& \sum_{i=1}^{l} V_{2 i}(t)=V_{2}(t), \quad t=\text { const } .
\end{aligned}
$$

$l$ - number of basic components, $l=5$ : methane (1), carbon dioxide (2), nitrogen (3), oxygen (4), hydrogen (5); $k_{2 i}$ - the share component of the gas. In the case of (3) the coefficients $k_{r i}$ is permanent and can be taken for a typical composition of the landfill gas: $\mathrm{CH}_{4}-0.474, \mathrm{CO}_{2}-0.47, \mathrm{~N}_{2}-0.037, \mathrm{O}_{2}-$ $0.0008, \mathrm{H}_{2}-0.0001, \mathrm{H}_{2} \mathrm{~S}-0.00001, \mathrm{CO}-0.0001$, paraffin carbohydrates - 0.0001, aromatic carbohydrates -0.0002 , trace components -0.0005 . In the case of (4) $k_{r i}$ change in chronological time $t$ [year] from stage to stage in the slow change in the concentration ratio of the components (see Fig.1).

The volume of landfill element: $V(x, y)=k \cdot M(x, y), \quad k=k_{1} k_{2} k_{3}$, where $\mathrm{V}(\mathrm{x}, y)$ - the volume of a cuboid formed by the $P$ area $\mathrm{k}_{1} \mathrm{k}_{2}$ $\left[\mathrm{m}^{2}\right], \mathrm{k}_{1}$ and $\mathrm{k}_{2}$ - the spatial resolution of the highrise image length and width, $\mathrm{k}_{3}$ - coefficient of transformation of COS in the physical units of height $[\mathrm{m}], \mathrm{M}(\mathrm{x}, \mathrm{y})$ - COS pixel $(\mathrm{x}, \mathrm{y})$ stereometric picture. 
The volume $\mathrm{V}$ of the dump body on the field $U$ : $V=\int_{(x, y) \in U} V(x, y) d x d y$.

Displacement $V_{s w 1}$ evaluated in terms of the corresponding element $V(x, y)$ or the whole body $V$ landfill: $\quad V_{\mathrm{swl}}(x, y)=k^{\prime} \cdot V(x, y), \quad V_{\mathrm{swl}}=k^{\prime} \cdot V$ where the coefficient $\mathrm{k}$ ' accounts for the ratio of the thicknesses of alternating insulating layers of soil and waste. This ratio may be considered waste and soil compacting, shrinkage ratio (by technological impact on surface and the impact on the depth of precipitation), and the final coating layer (nominal thickness of $2.5 \mathrm{~m}$ ). One can put a $\mathrm{k}^{\prime}=1$ (nominally [23] $\mathrm{k}^{\prime}=7 / 8: 2 \mathrm{~m} 0.25 \mathrm{~m}$ borne waste soil).

Own waste density $\rho_{s w l}^{\prime}$ spread on the storage map without sealing could be taken as the constant. In view of the seal $\rho_{s w l}$ waste density in the body of the landfill (landfill soil) $\rho_{s w l}=k^{\prime \prime} \rho_{s w l}^{\prime}$ where $k^{\prime \prime}=$ 1-4 - compression ratio. On the other hand, you can set $\rho_{s w l}=\rho_{\pi}$ - soil density, set time. In this case the landfill ground is modeled as a homogeneous throughout. Then the mass of solid waste: $m_{\mathrm{swl}}=\rho_{\mathrm{swl}} \cdot V_{\mathrm{swl}}$

The change in volume over time, that is the influx of new waste, can be found in space or aerial stereo images of high spatial (given $k_{1}, k_{2}$ ) and radiometric (given $k_{3}$ ) permission for the corresponding width of the time interval $\Delta t=t_{2}-t_{1}, t_{2}>t_{1}$ - moments of the shooting time. Spatial and temporal changes in the body and MSW in time:

$$
\begin{aligned}
& \Delta V(x, y)=V\left(x, y, t_{2}\right)-V\left(x, y, t_{1}\right), \\
& \Delta V=V\left(t_{2}\right)-V\left(t_{1}\right) \\
& \Delta V_{S W L}(x, y)=V_{S W L}\left(x, y, t_{2}\right)-V_{S W L}\left(x, y, t_{1}\right), \\
& \Delta V_{S W L}=V_{S W L}\left(t_{2}\right)-V_{S W L}\left(t_{1}\right)
\end{aligned}
$$

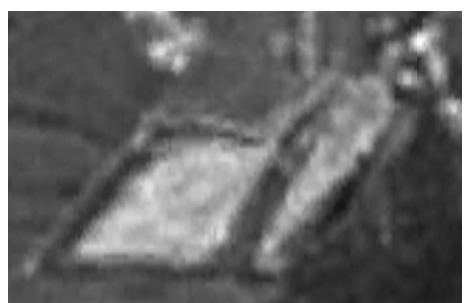

(a)

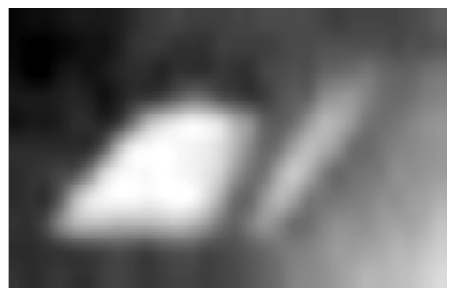

(b)
According to body - mass characteristics one can assess compliance with certain provisions of the legal regime of landfill operation. In particular, waste treatment income is estimated as a series $\left\{\Delta V_{S W L}\right\}$ of successive time intervals. Hence its difference from the nominal number of waste receipts evaluates violations in the amount of waste taken over the operation of the project and through a license agreement. Considering the density of component $\rho_{r i}$ biogas constant, its quantitative composition in biogas over a long period of time (e.g. one year): $\Delta m_{2 i}=\rho_{2 i} \cdot \Delta V_{2}, \Delta V_{2}$ - the volume of gas released from the landfill for a period of time (at nominal or actual receipt of waste, estimated from space or aerial photographs).

\section{RESULTS}

We show assessment of biogas yield and methane in the landfill Salaryevo example (Fig.3). In airborne image data volume of SWLs for 2000 gives: $V=1.12 * 10^{7} \mathrm{~m}^{3}$. Spatial resolution: length $k_{1}$ and $k_{2}$ width $-60 \mathrm{~m}$, height $k_{3}-1 \mathrm{~m}$. Then the error of amount estimation: $\varepsilon \sim L k_{1} k_{2} k_{3} \approx 4.1 * 10^{5} \mathrm{~m}^{3}$ ( $L=113$ - the number of pixels of the object on airborne image).

Total volume $V_{r}$ of biogas produced by the landfill for the time of its activity (as well as volumes of any other components of biogas) is the constant of the landfill and is calculated based on the maximum volume $\mathrm{V}$, which it takes to the final point in time of its operation. In 2000 the volume of $V_{w s l} \sim k^{\prime} V=V$ waste $\left(k^{\prime}=\right.$ $1)$, the total amount of biogas produced from a given amount of: $V_{2}=1.5 \mathrm{~V} \sim(2.52 \pm 0.062) \cdot 10^{7} \mathrm{M}^{3}$.

Fig. 3. Landfill Salaryevo: (a) a visible image (Google Earth, summer 1998); (b) the radar image (SRTM project, Winter, 2000); (c) 3D-model

Volumes of the main components of landfill gas can be taken on the basis of its average composition.
For example, assuming that the composition consists of $60 \%$ methane biogas [10], i.e. $k_{g i}=0.6, i=1$, 
we obtain the average volume of methane output $V_{g l}$ $=1.512 * 10^{7} \mathrm{~m}^{3}$. Assuming that the density of methane $\rho_{g l}=0.72 \mathrm{~kg} / \mathrm{m}^{3}$, its mass: $m_{g 1}=\rho_{g 1} \cdot V_{g 1} \sim 10886 \mathrm{t}$.

\section{CONCLUSIONS}

The design of a model of chemical transformations of matter on large landfills, together with the proposed method of assessment of chemical parameters of SWL by space images enables to assess the danger of biochemical degradation of the waste caused by the municipal landfills. The signs of hazardous chemical processes are often reflected on the surface. In particular, the filtrate of SWLs as a result of chemical transformations, being submitted to the surface, stores information about the main types of occurring chemical reactions. The comparison between in-situ (sampling and chemical analysis of the filtrate) and satellite data (spectral brightness curves of filtrate) and carrying out a regression analysis will reveal bandwidth (high intensity places spectral characteristics) of various fractions of matter, thus evaluating the contents of the substances on the satellite images of the filtrate.

\section{REFERENCES}

1. Yan-You Gou, Danielle E. Que, Chun-Yu Chuang, How-Ran Chao, Cherng-Gueih Shy, Yi-Chyun Hsu, Chun-Wen Lin, Kuo Pin Chuang, Chih-Chung Tsai, Lemmuel L. Tayo. (2016) Dust levels of polybrominated diphenyl ethers (PBDEs) and polybrominated dibenzo-p-dioxins, urans $(\mathrm{PBDD} / \mathrm{Fs})$ in the Taiwanese elementary school classrooms: Assessment of the risk to school-age children, Original Research Article, Science of The Total Environment, 572, 734-741.

2. Soňa Wimmerová, Martin van den Berg, Jana Chovancová, Henrieta Patayová, Todd A. Jusko, Majorie B.M. van Duursen, Lubica Palkovičová Murínová, Rocio F. Canton, Karin I. van Ede, Tomáš Trnovec. (2016)Relative effect potency estimates of dioxin-like activity for dioxins, furans, and dioxin-like PCBs in adults based on cytochrome P450 1A1 and 1B1 gene expression in blood, Original Research Article, Environment International, 96, 24-33.

3. Mukherjee A., B. Debnath, Sadhan Kumar Ghosh. (2016) A Review on Technologies of Removal of Dioxins and Furans from Incinerator Flue Gas, Original Research Article, Procedia Environmental Sciences, 35, 528-540.

4. Xiangli Shi, Ruiming Zhang, Haijun Zhang, Fei $\mathrm{Xu}$, Qingzhu Zhang, Wenxing Wang. (2015) Influence of water on the homogeneous gas-phase formation mechanism of polyhalogenated dioxins, furans from chlorinated, brominated phenols as precursors, Original Research Article, Chemosphere, 137, 142-148.

5. Jean Nizou, François Demory, Carole DubrulleBrunaud. (2016) Monitoring of dredged-dumped sediment dispersal off the Bay of the Seine (northern France) using environmental magnetism, Original Research Article, Comptes Rendus Geoscience, 348-6, 451-461.

6. Adam Smoliński, Leszek Drobek, Václav Dombek, Andrzej Bąk. (2016)Modeling of experimental data on trace elements and organic compounds content in industrial waste dumps, Original Research Article, Chemosphere, 162, 189-198.

7. Khalid Mahmood, Syeda Adila Batool, Muhammad Nawaz Chaudhry.(2016) Studying biothermal effects at and around MSW dumps using Satellite Remote Sensing and GIS, Original Research Article, Waste Management, 55, 118-128.

8. Jacek Bełdowski, Zygmunt Klusek, Marta Szubska, Raisa Turja, Anna I. Bulczak, Daniel Rak, Matthias Brenner, Thomas Lang, Lech Kotwicki, Katarzyna Grzelak, Jaromir Jakacki, Nicolai Fricke, Anders Östin, Ulf Olsson, Jacek Fabisiak, Galina Garnaga, Jenny Rattfelt Nyholm, Piotr Majewski, Katja Broeg, Martin Söderström, Paula Vanninen, et al. (2016)Chemical Munitions Search \& Assessment - An evaluation of the dumped munitions problem in the Baltic Sea, Original Research Article, Deep Sea Research Part II: Topical Studies in Oceanography, 128, 85-95.

9. Manish Kumar Tripathi, Mohammad Yasir, Pushpendra Singh, Iftikhar Asalm Tayubi, Rishikesh Gupta, Rahul Shrivastava. (2016) Toxic effect of chemicals dumped in premises of UCIL, Bhopal leading to environmental pollution: An in silico approach, Original Research Article/Asian Pacific Journal of Tropical Disease, 6 - 4, 284-290.

10. Putilin V.S., Galitskaya I.V., Yuganova T.I. (2005) Influence of organic matter on the migration of heavy metals in the areas of solid waste disposal. Analytical Review, Ecology series, 76. Novosibirsk. (in Russian)

11. Sakharov V.A., Morozov O.A., Vypryazhkin E.N., and Fayzulin K.H. (2015) The effect of the landfill of municipal solid waste in water bodies (for example, the city dump in the city of Yuzhno-Sakhalinsk), Science notes of the Sakhalin state University, 1 (11-12), 87-91.(in Russian)

12. Shamsieva G.S., Nyman S.M., Nyman M.O.(2014) Assessment of seepage water Samosyrovskoy landfill of Kazan, Ural Ecological Gazette. 2, 12.(in Russian) 
13. Filippova L.A., Jurkova I.V. (2009) Geochemical effect of small landfills on the environment, Proceedings of the Siberian Branch of the Section of Earth Sciences of the Russian Academy of Natural Sciences. Geology, searches and investigation of mineral deposits. 34 - 1, 92-106.(in Russian)

14. Shakhramanyan M.A., Richter A.A. (2013) Methods and space monitoring technologies of waste disposal facilities in order to ensure the environmental safety areas: Training handbook, Publishing Center of the Russian State University of Oil and Gas named after IM Gubkin, 241(in Russian)

15. Kristina Voigt, Hagen Scherb, Rainer Bruggemann, Karl-Werner Schramm.(2013) Discrete mathematical data analysis approach: A valuable assessment method for sustainable chemistry, Original Research Article, Science of The Total Environment, 454-455, 149-153.

16. Khodzhaniyazov H.W. (2016) New methods in teaching chemistry. 1. Mathematical methods for determining the amount of salt in the reactions of acids and Bronsted Lowry bases, Actual problems of the humanities and natural sciences, 7-1. 25-27.

17. Lozhkina E.M. (2016) Interdisciplinary communication of mathematics and chemistry at training to mathematical modeling in course of algebra of the basic school, Scientific look into the future. 31(1), 53-57.. (in Russian)
18. Richter A.A., Shakhramanyan M.A., Kazaryan M.L., Murynin A.B.(2015) Development of method for assessing the degree of soil degradation on the basis of long-term observations, Fundamental research, 2 - 14, 3095-3099.(in Russian)

19. Richter A.A., Kazaryan M.L., Shakhramanyan M.A. (2015) Processing of satellite images with the use of multimedia and its application in space monitoring facilities of waste disposal, Fundamental research, 8 -2, 328-332. (in Russian)

20. Shakhramanyan M.A., Kazaryan M.L., Richter A.A. (2016) Identification of debris according to satellite images of low spatial resolution Landsat, Information and Space, 3, 91-96. (in Russian)

21. Richter A., Kazaryan M., Shakhramanyan M., Nedkov R., Borisova D., Stankova N., Ivanova I., Zaharinova M.. Estimation of thermal characteristics of waste disposal sites using Landsat satellite images. Comptes rendus de l'Académie bulgare des Sciences (Proceedings of the Bulgarian Academy of Sciences), 70, 2, Издателство на БАН "Проф. Марин Дринов", 2017, 253-262.

22. Brovkina O. (2011) Remote monitoring of anthropogenic disturbances of taiga zone in North-West Russia, $\mathrm{PhD}$ thesis, 194. (in Russian)

23. Instructions for design, operation and reclamation of solid waste disposal sites. Moscow, 1998 (in Russian).

\title{
ОЦЕНКА НА ПАРАМЕТРИ НА ХИМИЧНИ ПРОЦЕСИ В ОБЕКТИ ЗА СЪХРАНЕНИЕ НА ОТПАДЫЦИ ПО САТЕЛИТНИ ИЗОБРАЖЕНИЯ
}

\author{
Михаил Шахраманян, Андрей Рихтер, Маретта Казарян, Румен Недков, Деница Борисова, Наталия \\ Станкова, Ива Иванова, Мариана Захаринова
}

Резюме. В настоящата работа се предлага методика за оценка на параметрите и характеристиките на химичните процеси в големи общински сметища и в обекти за съхранение на твърди отпадъци като се използват данни от дистанционен мониторинг на Земята. Описан е модел на химични преобразувания на веществата в местата за изхвърляне на отпадъци, който се основава на идеята за биохимичното разграждане на отпадъците и е показан под формата на "трансформационно дърво". Представянето на химичните трансформации под формата на статистически интегрирани химични уравнения ни позволява да опишем химичната система "съорьжение за обезвреждане на отпадъците" в аналитична форма. Работата включва основните физични (обем и маса, топлинна) и химични (филтрат) характеристики, чиито оценки могат да бъдат направени по данни от сателитни изображения. Като пример е описано получаването на обема и масата на сметището по неговия 3D-модел. Представени са резултатите от приложението на алгоритъма за района за съхранение на твърди битови и промишлени отпадъци в Саларево (Ленински район, Московска област). Като пример е приведена оценка на обема и масата на газа в сметището и на неговата основна съставка - метан. Аероснимка от 2000 година е сравнена със сателитни изображения във видимия спектрален диапазон от близки дати. Определени са основните източници на грешки при оценката на характеристиките обем и маса. Изчислена е грешката вследствие на ограничената пространствена и спектрална разделителна способност на използваните спътникови изображения.

Ключови думи: обектите за съхранение на отпадъци, сметища, спътникови изображения, химични процеси, 3D-модел 


\section{Mihail Shakhramanyan, Andrey Richter}

Researching Institute “AEROCOSMOS”, Gorohovskiy line, 4, 105064, Moscow, Russia e-mail: urfin17@yandex.ru; 7283963@mail.ru

\section{Maretta Kazaryan}

Financial University at Government of Russian Federation Vladikavkaz branch, Molodeghnaya str.7, 362001 Vladikavkaz, Russia,

e-mail: marettak@bk.ru

\section{Roumen Nedkov, Denitsa Borisova, Nataliya Stankova, Iva Ivanova, Mariana Zaharinova}

Space Research and Technology Institute, Bulgarian Academy of Sciences, Acad. G. Bonchev St, Bl. 1, 1113 Sofia, Bulgaria, e-mail: rnedkov@space.bas.bg

\section{Михаил Шахраманян, Андрей Рихтер}

НИИ АЭРОКОСМОС, 105064, Москва, Гороховский пер. 4, "АЭРОКОСМОС" e-mail: urfin17@yandex.ru; 7283963@mail.ru

\section{Маретта Казарян}

«Владикавказский филиал Финансового университета при Правительстве Российской Федерации», Россия, 362001, Владикавказ, ул. Молодежная, 7 e-mail: vfek@bk.ru

\section{Румен Недков, Деница Борисова, Наталия Станкова, Ива Иванова, Мариана Захаринова}

Институт за космически изследвания и технологии-Българска академия на науките, България, София 1113, ул. Акад. Г. Бончев, бл. 1

e-mail: rnedkov@space.bas.bg 